\title{
THE CAPITALIST VERSUS COMMUNIST PROPAGANDA DURING THE COLD WAR
}

\author{
Sahul Hamid Mohamed Maiddin
}

\begin{abstract}
This article examines the differences between the Capitalist and the Communist propaganda and indoctrination carried out during the early Cold War period. The Capitalist is represented by the United States of America and Britain, while the Communist is represented by the Soviet Union and the People's Republic of China. They confronted each other with series of propaganda to belittle each other and simultaneously strengthen their own positions in the domestic and international politics. In this article, two major distinguishable traits of propaganda are the propaganda of ideology and the propaganda of personality. This article also discusses briefly the background of the propaganda in both sides. Later, it presents some illustrative examples to provide a lucid comprehension regarding the subjects. This article concludes that the Communist had more tendencies in mobilising the propaganda of personality compared to the Capitalist. This article is based mainly on sources from newspapers, online sources including declassified official documents and correspondences, journals, and books.
\end{abstract}

\section{Introduction}

The Cold War (1945-1991) was the apogee of the twentieth-century struggle for the hearts and minds. It was by its very nature a global propaganda conflict, the alternative to a real war. The Cold War witnessed a transition of superpower status, from Britain to the United States of America after the end of the Second World War (WW2). Simultaneously, the emergence of the Soviet Union and its control of 
the Eastern Europe created a conflict between these newly emerged superpowers.

This article which covers the early Cold War period begins with an introduction on the Capitalist and Communist propaganda to provide a basic understanding of the fundamental of their propaganda respectively. The Capitalist refers here particularly to the United States (US) and Britain. However, the focus will be more on the US because of its intensity and involvement. Conversely, in representing the Communist, the Soviet Union and China are examined simultaneously for their critical roles in the Cold War propaganda. Consequently, the discourse is directed to the major differences between Capitalist and Communist propaganda.

The article demonstrates their particular methods and machineries for disseminating propaganda and indoctrination, domestically and abroad. It also provides some illustrations in relation to the propaganda from both sides of the bloc, chiefly pertaining to the cult of personality. It shows that the Communist propaganda had more predisposition in manipulating images compared to the Capitalist. On the other hand, for Capitalist, the focus was centered on the achievement of wealth and the freedom of individuals. Although many scholarly works have been done to examine the Cold War propaganda, none had illustratively distinguish the propaganda approach between the Capitalist and the Communist, not to mention specifically on the propaganda of personality, as this article attempted to discuss.

\section{A Background to the Capitalist and Communist Propaganda ${ }^{1}$}

In August 1945, President Harry S. Truman concluded that the Washington still needed an overseas propaganda program, but the wartime agencies, the Office of War Information (OWI), would have to be replaced with new information services. Thus, Truman issued an executive order abolishing the OWI on $31^{\text {st }}$ August $1945 .{ }^{2}$ However, after two years, a consensus emerged in 1947 to establish a postwar propaganda effort as a result of the onset of the Cold War ${ }^{3}$ with the Soviet Union. This was also hastened by the inception of the Soviet Union's Cominform (Communist Information Bureau) which delivered propaganda broadsides against the Marshall Plan ${ }^{4}$ in September 1947. ${ }^{5}$

In April 1948, the armed service of US pressed the government to set up an independent psychological warfare agency under the National Security Council. ${ }^{6}$ Again, on $4^{\text {th }}$ May 1948, in relation to the inauguration of an organized psychological/political warfare agency, a memorandum was presented to analyze the necessity for political warfare. According to the memorandum, the political warfare which 
meant to employ all the means at nation's command to achieve national objectives was one of the primary reasons for its creation, success and survival. This memorandum also suggested a range of operations, both overt and covert actions. Overt actions consisted of political alliances, economic measures and white propagand ${ }^{7}$ whereas covert operations consisted of support for 'friendly' foreign elements, black propaganda ${ }^{8}$ and encouragement of underground resistance in hostile states. ${ }^{9}$

In exercising these actions, in 1954, the US moved to overthrow the democratic government of Guatemala and installed a murderous death-squad society with constant infusions of US aid. ${ }^{10}$ Besides, US, the Central Intelligence Agency (CIA) and the United States Information Agency (USIA), also carried out the Operation Mongoose in Cuba in order to overthrow its President, Fidel Castro. ${ }^{11}$ The CIA task was to gather and provide intelligence report whereas the propaganda programs to isolate Castro was assigned to the USIA. The US also strove to strengthen, maintain and exploit the will of Cuban people to resist Castro-Communism. ${ }^{12}$

The creation of the Central Intelligence Agency (CIA) under the National Security Act of 1947 was in response to the need to launch a campaign of 'peacetime' psychological warfare that aimed to undermine the Soviet and East European regimes. ${ }^{13}$ For the US, this measure is vital to counter the aggressive Soviet political warfare, which remarked as "the full might of the Kremlin's political warfare...the most refined and effective of any in history". ${ }^{14}$ The creation of the CIA reflected a consensus on the need for a modern intelligence-gathering apparatus as well as to perform some unspecified, ambiguous functions. The clause, 'to perform some unspecified, ambiguous functions', which was interpreted by the national security elites as a 'licence' [sic] to launch coups against undesirable governments and even assassination of foreign leaders, further supplemented in a discourse by the CIA senior officials in October 1948. ${ }^{15}$ As a result, it was then suggested to establish five functional groups, each one with its own task. The first group, under the title of 'psychological warfare' was responsible for press, radio, and miscellaneous (direct mail, poison-pen letters and rumors). ${ }^{16}$

The second group, with the function of 'political warfare' was responsible for support of underground resistance, refugees, antiCommunists in Free Countries and encouragement of defection. Group three, under the banner of 'economic warfare' is responsible for commodity operations, including clandestine preclusive buying, market manipulation and black market operations as well as fiscal operations such as currency speculation and counterfeiting. The fourth group, 'preventive direct action' was to undertake sabotage, counter-sabotage and demolition; and support of guerrillas. The last group on the list 
was responsible for 'miscellaneous activities' which consisted of front organization, war plans and administration. ${ }^{17}$

The United States mobilized its resources in every possible ways to overcome the rivals, the Communists, in order to entrench the Capitalist ideology. In the United Nations (UN), the US also planned to launch its propaganda whenever the objective was primarily to influence the attitudes of others, by communicating to them (through either words or actions) broad ideas or concepts. However, whenever the objective was primarily to attain certain diplomatic results, without primary consideration to how these may affect the attitudes of others, the US spoke the substantive policies. ${ }^{18}$ The US's main objective was to lead the targeted group namely the Arab-Asian to fuller understanding of the threat of the Soviet system, and to increase support on the anti-Soviet measures. ${ }^{19}$ Obviously, the Soviet Union has wielded its propaganda as a powerful instrument of the Cold War, with the UN as one of its favored platform and sounding boards. The US has had to accept the Soviet challenge and intensify its propaganda activities.

The Communist propaganda arrived in US and Britain, mainly in the form of magazines, books, pamphlets, newspapers, and films. For example, in 1957, in Hong Kong, the Soviet and China co-operated to make a film portraying the British police as unfriendly and cruel, kicking and beating a small boy. ${ }^{20}$ There was also a Chinese literature piece encountered in Britain, designed to illustrate the cowardice of the UN troops in Korea during the Korean War. It was concurrent with the Chinese campaign of proving that the West was a 'paper tiger' ${ }^{21}$ In addition, anti-capitalists propaganda was also disseminated discreetly through business entity.

A London-based company, J.G Booth Smith and Co. Ltd., which had a business transaction with a Chinese company, 'The China National Tea and Native Produce Import and Export Corporation', once expressed its grievances to the House of Common about the intense anti-US propaganda leaflets enclosed in trade magazines. The illustrated white propaganda leaflets which titled 'Heroes and Heroines of South Vietnam' censured the United States imperialism in Vietnam. ${ }^{22}$ Among the disturbing lines in the preface of the leaflets read, "Patriots are beheaded, skinned and buried alive...the US imperialists are spraying toxic chemicals from airplanes to destroy crops and poison the people and livestock in South Vietnam." 23

The Communist propaganda and indoctrination were explained in the United States' documents as consisting two phases. ${ }^{24}$ The first is the preparatory phase entailing 'softening-up' or 'conditioning', carried out through the medium of a series of lectures on the imperfections of the government under which the prisoners live before capture. ${ }^{25}$ 
The next phase is the implementation phase. It is devoted to selling communism as a way of life to be preferred over the democratic system. ${ }^{26}$ The Communist state portrayed as a state in which people live a life of happiness, free of poverty and class discrimination. This document itself, in actual fact, was a document of propaganda and indoctrination for the US servicemen. The document begins with an inspiring quotation from Thomas Jefferson, the founding father and the third President of the US, "Resistance to tyrants is obedience to god". ${ }^{27}$ The quotation is abstract, and is a universal value, nevertheless, implicitly provide an impression that fighting for the country means abiding to the God's commands. The document further stated that "an indomitable will to resist is not acquired overnight. Nor can be it supplied by military training alone. It rests on character traits instilled in our homes, our schools, our churches - traits such as self-discipline... and faith in country and God" ${ }^{28}$ Here, the importance of institutions like schools and religious houses were emphasized, demonstrating its vital roles for indoctrination.

\section{Capitalist and Communist Propaganda: What Makes Them Different?}

Propaganda during the Cold War witnessed its dexterity and intensity on denigrating each other; Capitalists, by US and Britain, against Communists, mainly by the Soviet Union and China, and vice versa. On 24 July 1959, during an American exhibition in Moscow, the Soviet Premier, Nikita Khrushchev met the US Vice President Richard Nixon and had an exchange of thoughts, which was popularly known as the 'Kitchen Debate', about their understanding on each other's ideologies and achievements. Khrushchev had criticized the US technology in housing development by accusing that the American houses are built to last only for 20 years whereas in Soviet, "...we build it firmly. We build for our children and grandchildren." 29

Refuting this accusation, Nixon claimed that "... after 20 years, many Americans want a new house or a new kitchen...The American system is designed to take advantage of new inventions and new techniques". ${ }^{30}$ For Khrushchev, "the Americans have created their own image of the Soviet man" But he [the Russians] is not as you think." Addressing Khrushchev as a filibusterer for his argumentative attitude, Nixon replied "You can learn from us and we can learn from you. There must be a free exchange." 31 The conversation ended with a mutual agreement that the both side of the bloc has very limited understanding and interpretation about each other's perceptions, despite the fact that the exhibition was organized to promote the understanding between 
them. Khrushchev, representing the Soviet, was perceived as more aggressive and dominant as compared to Nixon.

The Soviet Union claimed to be a peace-loving country and peaceloving people, against the danger of war, which implicitly pointed to the Capitalist. ${ }^{32}$ The Soviet Union and later with China, depicted themselves as the liberators of the third world nations. Armed with Marxism-Leninism, the well experienced and all conquering Soviet Union Communist Party had always served as an example and teacher for the Chinese Communist Party ${ }^{33}$ Despite sharing the same ideology, these pillars of communism had some differences as assessed by the officials in the Research Department, Great Britain. However, according to the research, to study the differences between these two kinds of communism was like comparing an Indian and African elephant; when all has been said, they are elephants, and the Communists are communists. The summary of the research noted that unlike the Soviet communists, the Chinese communists had co-operated with bourgeoisie, and regard them as having accomplished a 'new-type bourgeoisdemocratic revolution', not a proletariat revolution. In some practical matters, the Chinese communists have had so far a smoother path than the Soviet communists because they have profited from the latter's experience and mistakes, and also from their mistakes. ${ }^{34}$

Generally, two major traits shall be highlighted to differentiate the Capitalist and Communist propaganda. First, the propaganda of ideology and second, the propaganda of personality. The first and foremost noteworthy different between these two blocs was the war of ideologies. The West, referring to the United States and Britain, represented the gleaming image of capitalism whilst the Soviet Union and its closest ally after the Second World War, China, represented the glaring image of communism. This was evident in a Foreign Office document of December 1951 which pointed out "The cold war is a struggle for men's minds. It is a struggle to determine whether the mass of mankind shall look for hope towards the Soviet Union or towards the Western democracies". ${ }^{35}$ They respectively strove to disseminate their ideology, in own land, and more intensively abroad. Propaganda abroad was essential to gain the confidence, respect and support of the world by portraying the superiority of the ideology in achieving progressive lifestyle. In the first place, the task to carry out the propaganda was assign to the different agencies in both sides. For the Capitalist; in US the task was assigned mainly to the United States Information Agency (USIA), whereas in Britain it was assigned to the Information Research Department (IRD) ${ }^{36}$ For the Communist; both in the Soviet Union and China, the role of propagandist was vested on their Communist Party, respectively. 
In Soviet, it was carried out by the Department of Agitation and Propaganda aka Agitprop, a section of the Soviet Communist Party Central Committee. Agitprop had primary responsibility for domestic and foreign propaganda policy, training and supervision. ${ }^{37}$ Agitprop across the world worked under the auspices of the Department of Agitation and Propaganda of the Executive Committee of Communist International, established in August 1924. The work of the department was divided to four sub-departments namely sub-department for agitation, sub-department for propaganda, sub-department for press and publication and sub-department to collate the experiences of the sections. ${ }^{38}$ The first sub-department was assigned to popularize the idea and slogans of the Comintern and to work out and communicate the methods, forms and techniques of mass agitation. On the other hand, the sub-department for propaganda was tasked to work out the forms and methods of education work within the party. It also helped to draw up and circulate material for education, curricula for party schools and lecture courses using Marxist materials. For the press sub-department, its main task was to guide and supervise the communist party press and publications, and to issue instruction for them. ${ }^{39}$

In China, similar tasks were carried out by The Department of Propaganda of the Central Committee of the Communist Party. Like its Soviet counterpart, the Department determined the content of propaganda and indoctrination, makes general plans for its conduct, trains and places personnel in this field, and controls the development of propaganda media and indoctrination facilities. ${ }^{40}$ Here is the contrast, in the capitalist countries, government agencies - disregard of which political party runs the government - acted as propagandists whereas in the communist countries, it was carried out by the ruling party itself, where only the Communist party perpetually holds the power.

In US, the USIA found its niche by devising and carrying out anti-communist propaganda programs based on three primary themes namely denounce communism, exalt the capitalist system and promote democracy. ${ }^{41}$ It promoted these themes through both overt and covert means. The department took an offensive stance in the propaganda battle against the Soviet Union and her allies, when there was a notion that future conflicts would not necessarily involve direct military aggression, but rather overt and covert ideological actions with the production and distribution of propaganda materials. Overt actions were executed through print communications, broadcast news, films, books and libraries programs, exhibition and exchange programs. ${ }^{42}$ As the covert actions concerned, it was carried out by the USIA with a close assistance of the CIA, such as in Cuba and few other communist leaning countries in Western Europe, Eastern Europe, Near East, Far East and 
Latin America. Among the actions planned were propaganda, sabotage and subversive namely by assisting underground resistance movements, assisting guerillas and support to the anti-Communist elements in the threatened countries. ${ }^{43}$ Subversive activities in dooming the communist ideology and supporters were the most popular approach by the CIA which was evident in Cuba by sheer endeavor to overthrow President Fidel Castro regime in 1962. The total estimated sum of $\$ 40$ million and $\$ 60$ million allotted for this tasks in 1963 and 1964 respectively, with numbers of CIA personnel engaged full time were more than $600 .{ }^{44}$

Contrarily, in the Soviet Union and China, there was no clear evidence of such subversive foreign propaganda activities entailed in overthrowing any regimes in the world. Conversely, the Communist foreign propaganda was aimed to condemn the US and its agency such as NATO (North Atlantic Treaty Organization), boasting of the Soviet's scientific-military superiority over the US, and convincing prospect countries as having a common cause of all working and peace-minded people. The Soviet Union continued to pose as the protector of the world-peace and manipulated some international movements like the Afro-Asian People's Solidarity Council and The World Peace Council to try to set local national aspirations against the unabated threat of Western neocolonialism. ${ }^{45}$

Ideologically, for the US, one of the most important propaganda terms in 1950s was the coining of the 'People's Capitalism' during Eisenhower's tenure. Originated by Eisenhower's adviser, T.S. Repplier, the term was an attempt to trumpet US material prosperity and individual opportunity to the world. ${ }^{46}$ Purported to counteract the Communist propaganda, partially with the call for 'peaceful coexistence' by Nikita Khrushchev ${ }^{47}$, the task to propagate this term was assigned to the USIA by the means of print, film, trade fairs, exhibitions, and exchange programs to nurture a benevolent image of capitalism. In contrast to the Communists-inspired dichotomy of oppressed and a vicious ruling class, 'People's Capitalism' emphasized rising incomes and the growth of the American middle-class. Under this concept, propagandists also asserted that the US had evolved the highest standard of living in the world, with its accomplishments in automation, and new business, social security, hospitalization benefits, labor unions, public education, and the finest university system in the world. ${ }^{48}$ Providing vast opportunities for the personal affluences, the Capitalist propaganda was actually directed to the general public, disregard of their socioeconomics background.

On the other hand, clinging to the concept of 'masses' and 'oppressed' classes signified by the term "proletariats", the Communist propaganda, headed by the Department of Agitation and Propaganda 
(Agitprop), directed their propaganda predominantly to workers, peasants and youths. The proponents of this concept, Marx and Engel in $19^{\text {th }}$ century asserted that, "The proletariat goes through various stages of development. With its birth begins its struggle with the bourgeoisie. At first the contest is carried on by individual laborers, then by the workpeople of a factory, then by the operatives of one trade, in one locality, against the individual bourgeois who directly exploits them" ${ }^{49}$ Subsequently, they further stressed that, "The lower middle class, the small manufacturer, the shopkeeper, the artisan, the peasant, all these fight against the bourgeoisie, to save from extinction their existence as fractions of the middle class"..$^{50}$

The Soviet Union and China consistently mobilized the working classes in attempt to portray the capitalist forces as decaying and disintegrating forces of modern society and socialist forces as the rising forces to be speeded to victory. Stalin, the Soviet Union leader prior 1953, emphasized on the needs to mobilize the masses into a great army in order to smash the reactionary forces, the bourgeoisie, and to clear the way for the advanced forces of the society. ${ }^{51}$ The Communists regarded this movement as 'internationalism' 52 , namely the solidarity of the workers regardless of national boundary, race or religions. Therefore, the Communist always exploit the mass organizations, with each of them had the responsibility for rallying a certain special group around it in support of the regime. Among all were workers and youths to propagate their ideology worldwide, for instance, The World Federation of Trade Unions, International Union of Students and the World Federation of Scientific Workers. ${ }^{53}$

Another major device for propagating the Communist ideology, which was absent in the Capitalist propaganda, was the specially formulated party schools. The schools were intended for indoctrinating cadres to uphold the Communist ideology and purvey it to the masses. In China, as of October 1957, party committees above the provincial level maintained seventy senior, secondary and junior party schools in addition to the party schools set up by administrative districts in 22 provinces, and the party schools of county committees set up in 17 provinces. Beside these, the party committees at different levels had also set up at different time more than 1000 spare-time political schools. The system made it possible to indoctrinate large numbers of students throughout China. As a result, from 1949 to March 1950, party schools on the provinces Hopei, Shansi and Pingyuan assembled more than 200,000 village cadres to study the agricultural policy of the regime.

In 1953, party schools in Honan [sic] province alone had a total enrolment of 250,000 rural officials. ${ }^{54}$ In the Soviet Union, the need for establishment of party schools was spurred by Stalin's First Five-Year 
Plan in 1928, from which he initiated the total reorganization of the Soviet Union's educational system. The core elements of party school system devised by Stalin were top-down centralized control, close coordination with Soviet industrial needs, the elimination of social science courses and replacement with courses in Marxist-Leninist ideology and finally the vigorous recruitment and placement of proletariat students. ${ }^{55}$

The propaganda of ideology between the Capitalist and Communist was further blazing in the form of arts. Within the fine art establishment, Western art and artists, with aesthetic images, were portrayed as external enemies that posed a threat to the ideology of the Communist system. In 1946, the Central Committee of the Communist Party clarified in its decree on fine art and visual arts that all forms of intellectual activity in the Soviet Union must serve political ends, and there can be no art or science for its own sake or for the sake of beauty and truth. ${ }^{56}$ Vladimir Kemenov, an art critic, identified a clear distinction between the 'antihumanism' of the 'reactionary bourgeois art of the imperialist era' and the egalitarian principles of the 'highest, most progressive' culture of the Soviet Union. This distinction was the result of a long process of the Western artistic decline which began with the rise of aestheticism in the mid-nineteenth century. ${ }^{57}$

Associating this type of 'Socialist Realism' art with the egalitarian principle of Marxism-Leninism, Kemenov argued that it was built upon the ideas of patriotism and equality; ideas of brotherhood of the peoples; ideas of humanism, the struggle for the individual freedom; and ideas of the emancipation of the labour and the freedom of women. ${ }^{58}$ Offensive measures against the Western art and culture went further with the liquidation of the Moscow Museum of New Western Art. With Stalin's consent, in 1948, the museum was shut down swiftly and without publicity, and the building was transformed to the newlyformed Academy of the Arts to promote the art of 'Socialist Realism'.

Similarly, the idea of 'Socialist Realism' was prevalence in China, and widely practiced with an utmost encouragement from Mao Zedong, the Chairman of the Communist Party of China. To Mao, "there is in fact no such thing as art for art's sake. Art that stands above classes, art that detached from or independent of politics". ${ }^{59}$ Setting up his own propaganda organization in 1962, Mao stressed on need to create more arts and literary works in order to disseminate his socialist revolutionary thought with emphasize on the peasants and workers classes. Mao affirmed that, "The richest source of power to wage war lies in the masses of the people". ${ }^{60}$ 
Figure 1: A child's dream - The stars light up the sky, I want to observe them closely through my telescope. I shall one day fly into space and the most modern scientific ideas into reality. Shanghai People's Art Publishing House, 1960

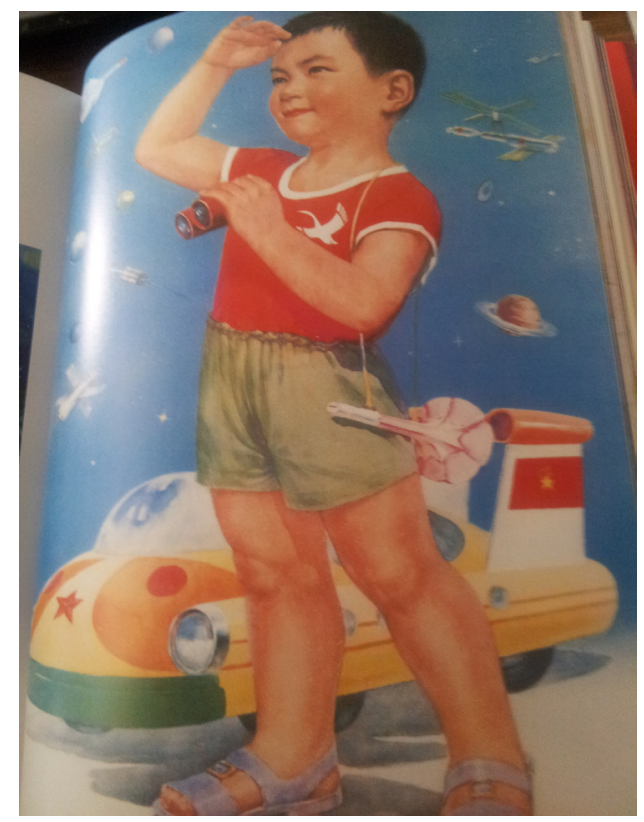

Source: Chinese Propaganda Posters from the Collection of Michael Wolf, Koln: Taschen, 2008, p. 234.

Propaganda posters, the most executed means of Mao's propaganda, were published in Shanghai, the major Maoist political stronghold and China's largest publishing center. Poster themes ranged from promoting the Cultural Revolution and criticizing Mao's opponents, and from furthering anti-imperialist foreign policy to entrenching patriotism in his people (Figure 1, 2, and 3). ${ }^{61}$

The propaganda posters were presented in vivid and colorful ways in order to penetrate every level of social organization and groups. Glittering images with political slogans allowed it to be permeated in an almost subconscious manner. The years of the great mass movements such as the Great Leap Forward (1958-1960) and the subsequent Cultural Revolution, when millions of people were mobilized into action, witnessed the climax in poster productions. 
Figure 2: Answer the call of Chairman Mao with determination and support the revolution in the countryside. Top left: "In the interest of the people, lay in stores of grain in case of war or natural disaster. On the booklet: Quotations of Chairman Mao Zedong. Shanghai People's Art Publishing House, 1970s

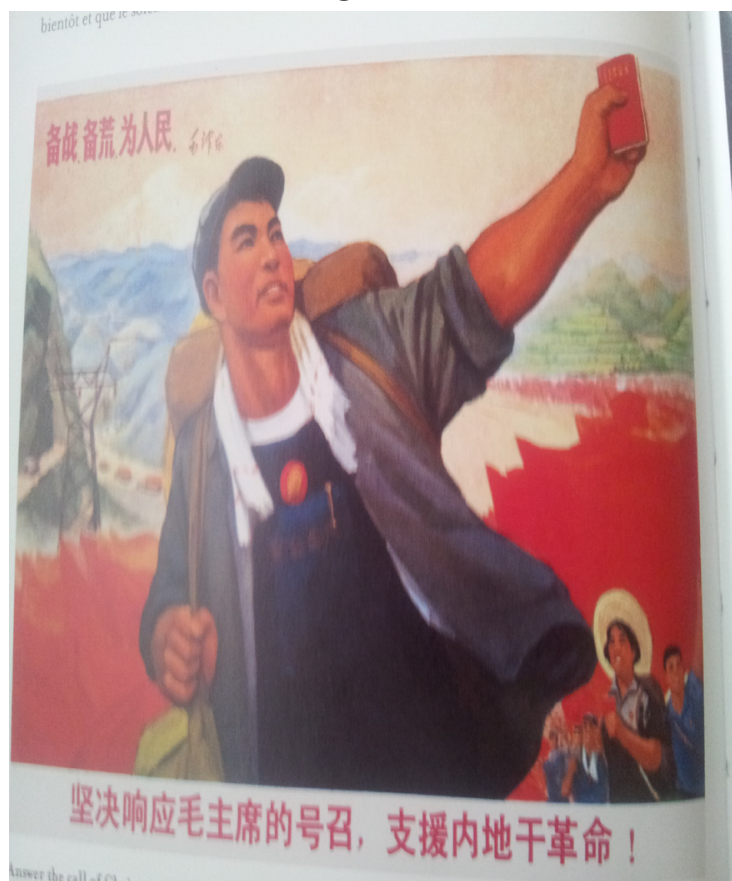

Source: Chinese Propaganda Posters from the Collection of Michael Wolf, Koln: Taschen, 2008, p. 104.

The propaganda of personality was another category of propaganda, which gained currency during the Cold War, particularly in the Communist countries. This type of propaganda focuses on the human personality or traits which can be exploited, whether to be perceived as sacred as an angel or as wicked as a witch. The objective is to denounce or to deify. While the Capitalist was tending to denounce their opponents, relatively the Communist was having more interest at deifying, also known as cult of personality, and had lesser interest in denouncing the opponents' personality. There were no clear evidence of deification by any means of the Capitalist propaganda during the Cold War, albeit Winston Churchill of Britain was later addressed as 'a prophet of the Cold War'62, while abundance of works can easily be found on the other side of the bloc. In the Communist system, it was obvious that 'one man command and the rest obey'. Therefore, the 'one man', which tantamount to dictatorship, should always be portrayed 
as sacred, supreme, and sturdy in order to make the people remain subjugated and susceptible to the political appeals. Among the most popular means of propaganda of personality were the manipulation of caricatures and cartoons; art and literary works such as posters, poems and motion pictures; bestowal of titles; and rhetoric in speeches.

Figure 3: Down with US imperialism. Yankees get out of Dominica. Shanghai Printing Press of Zhong Hua Publishing House, 1965

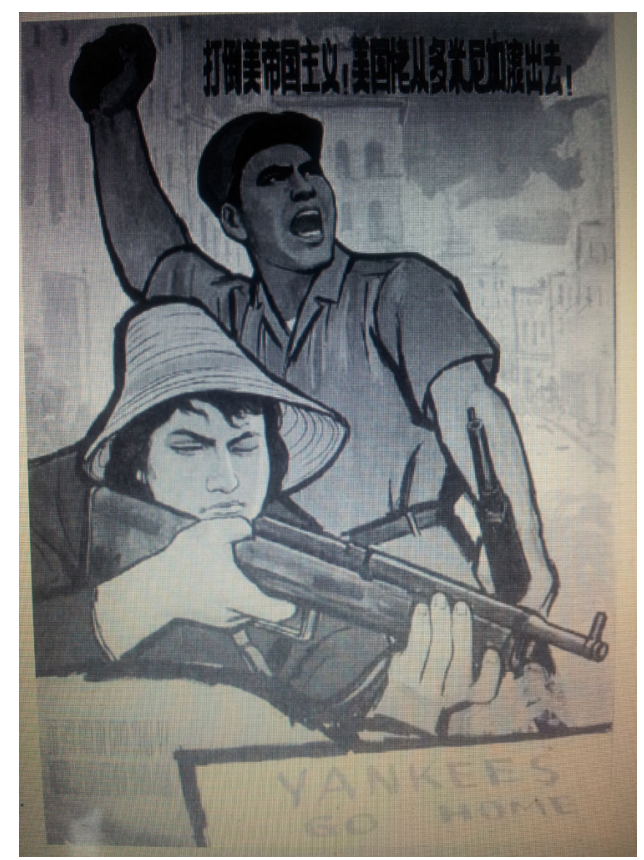

Source: Patricia Powell and Joseph Wong, "Propaganda Posters from the Chinese Cultural Revolution", p. 788

From the outset of the Cold War, in the Soviet Union, political cartooning was markedly different in style and content from that of the West. ${ }^{63}$ The cartoons were blatant propaganda tools of the regime. Both Stalin and his successor Khrushchev adamantly believed that the press was the communist elite's most potent ideological weapon. In contrast to the Soviet control, the relative independence of the press in the West meant it could choose to follow its own agenda, whether on the political right or left. For instance, the UK published Communist Daily Worker toed the Soviet line throughout the Cold War with little interference from the British Government. Pavel Sautikov, the editor of Pravda 
under Khrushchev, believed that the most important responsibility of a Soviet cartoonist was 'great sensitivity to the party's needs' ${ }^{64}$

Interestingly, no single caricature of Stalin was published in any of the Soviet press while he was alive. The reason was because of Stalin's stringent standard on his own caricature, which to the extent that can lead to the cartoonist death if perceived as failed to comply with the standard. Hence, the first image of Stalin was only published on 7 March 1953, two days after his death, to eulogize his work and teaching (Figure 4). Meanwhile, the first Soviet political leader's cartoon to be published after the Second World War was of Khrushchev's image drilling the Cold War snowman (Figure 5). In contrast to this deification, the Capitalist published some cartoons to disparage and denounce the Communist leaders (Figure 6 and 7). The drawing of opponent's leaders often shown in a clumsy appearance and gloomy image, while own leaders' images were shown in a neat and vigorous appearance.

Figure 4: Stalin's image shows eternity of his teaching and works, as well as his omnipresence among his followers. Jimmy Friell (Gabriel), Daily Worker, 7 March 1953

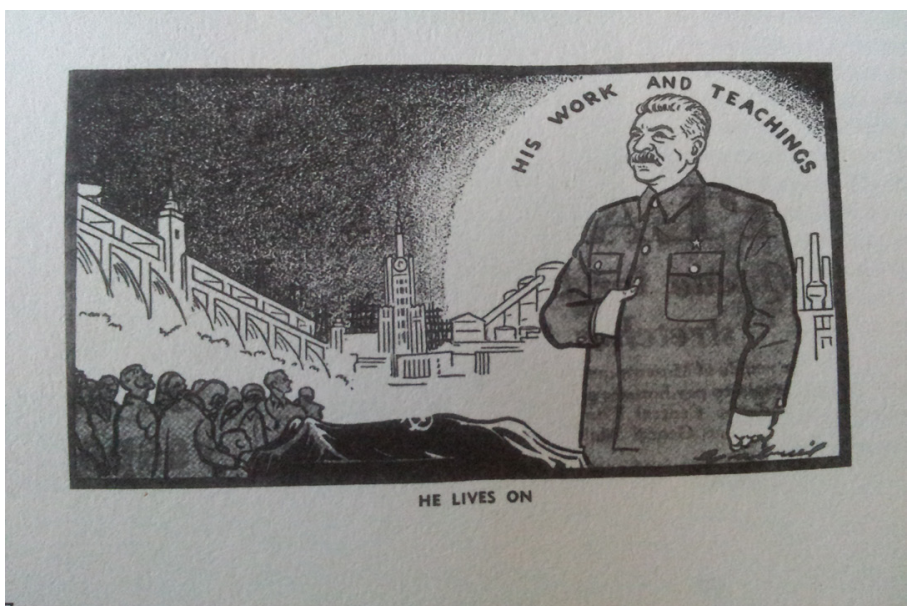

Source: Timothy S. Benson, "The Cartoonists' Cold War", Frank Althaus \& Mark Sutcliffe (eds.), The Cold War in Cartoons, Drawing the Curtain, London: Fontanka Publications, 2012, p. 11. 
Figure 5: Nikita Khrushchev attacking the Cold War snowman representing one of the periodic thaws in the Cold War. Text on hat: Cold War. Boris Efimov, Pravda, 1 January 1960

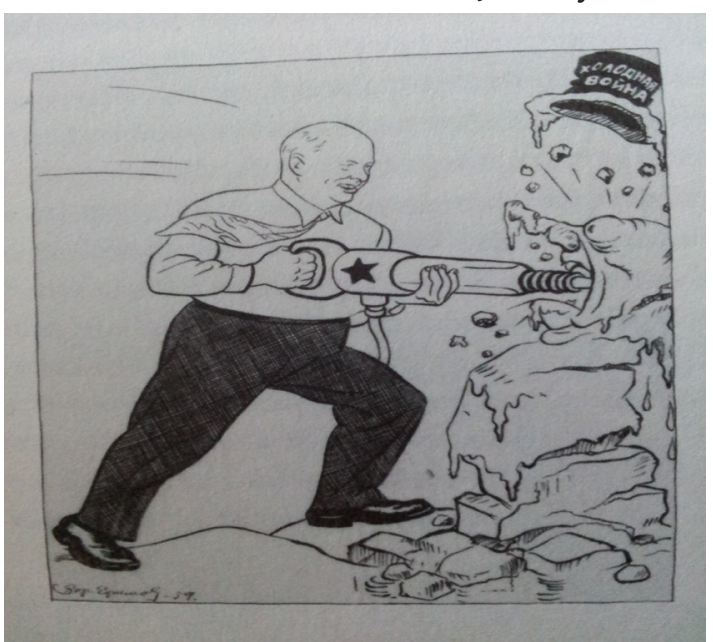

Source: Timothy S. Benson, “The Cartoonists' Cold War", Frank Althaus \& Mark Sutcliffe (eds.), The Cold War in Cartoons, Drawing the Curtain, London: Fontanka Publications, 2012, p. 11

Figure 6: The Stalin's image shows his propaganda 'chemicals' with full of lies and hatred. Laszlo Fodor, 1951

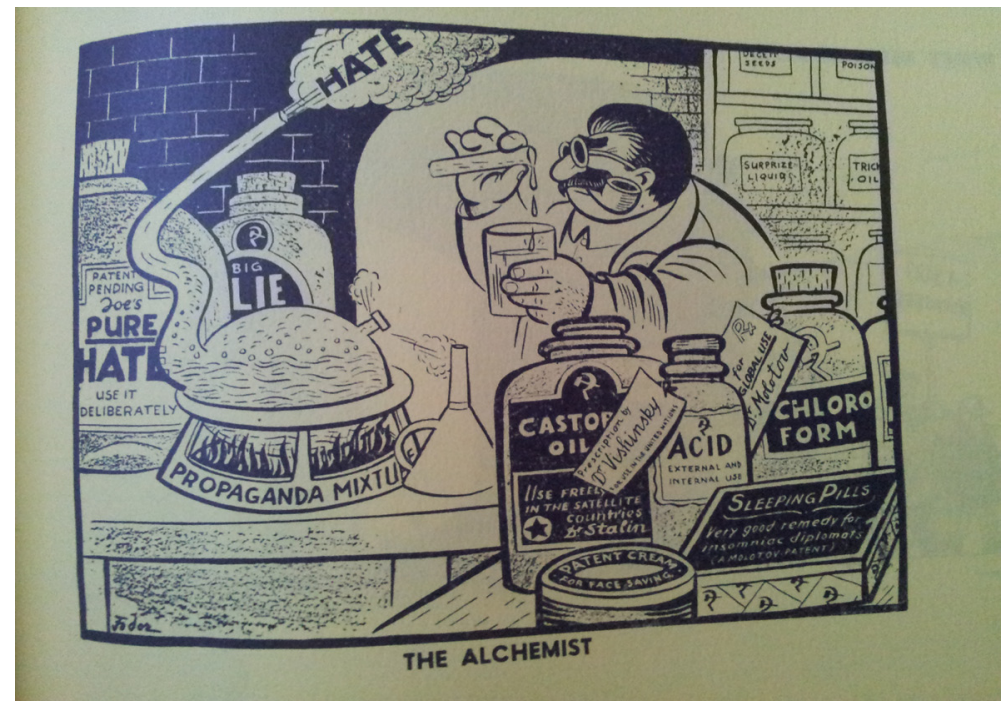

Source: Laszlo Fodor \& Adrian B. Lopez (eds.), Stalin's lie: Cartoons, jokes and stories from behind the Iron Curtain, New York: Picturight, 1951, p. 23. 
Figure 7: This war leaflet's cartoon shows the image resembling Chinese Communist leader, Mao Zedong as an instigator of war in Vietnam. He's depicted as responsible for the death of North Vietnamese

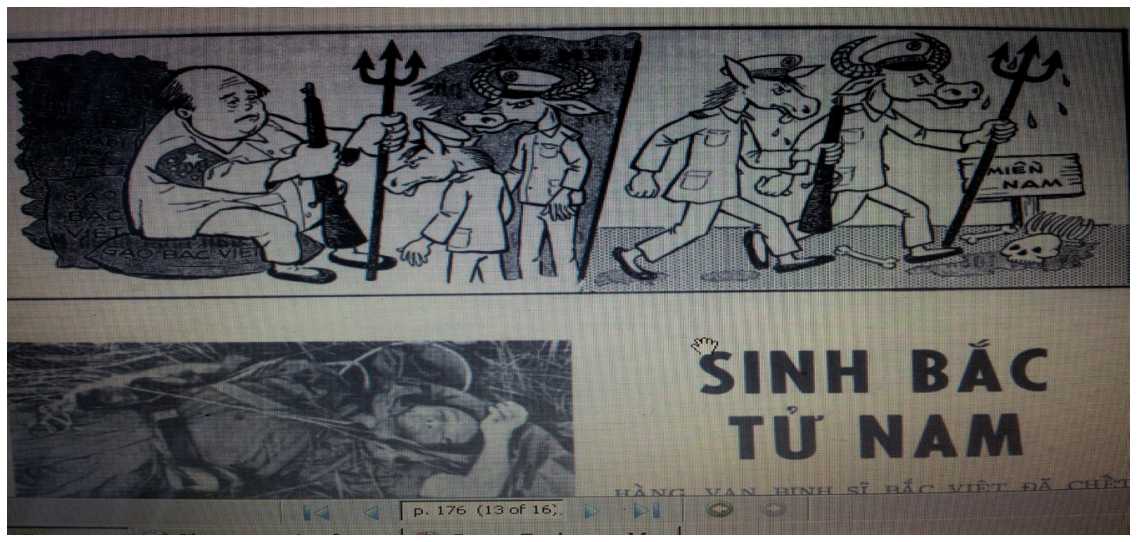

Source: Cited in James O. Whittaker, "Psychological Warfare in Vietnam", Political Psychology, Vol. 18, No. 1, March 1997, p. 176.

Propaganda posters were among the most popular methods for glorifying the leaders in history. In China, throughout its long history, arts became a prominent mean to disseminate ideology and to educate the masses. Once the People Republic of China was established in 1949, propaganda posters began to be distributed across the nation in order to convince the people on the capabilities of the Communist Party and converging allegiance to Mao Zedong. This propaganda was escalated particularly during the year of the Great Leap Forward (1958-1960) and (1966-1976). During these years, Chairman Mao seemed to have become the only permissible subject of the era. ${ }^{65}$ His face used to be painted in red and other warm tones, to provide a glittering effect, and also to become a source of light to illuminate his people like a sunlight (Figure 8). Mao also became a regular presence in every home, usually in the form of his official portrait and posters (Figure 9).

As mentioned earlier, a dictatorship reign - which is obvious in one party system of communist states - had always inclined to utilize this type of propaganda to legitimate their source of power, and to instill a sense of allegiance through this type of somewhat 'superstitious' method. In the Soviet Union, Stalin was the most celebrated leader after Lenin, particularly in the beginning of the Cold War. For example, Stalin was depicted as standing in the centre of the world with all the audiences eyes converged to him with full of hope and confidence (Figure 10). Indeed, Stalin and Mao were both enjoyed the status of greatest leader respectively and their influences are extant to date. ${ }^{66}$ 
Figure 8: Mao at the height of his worship, appears as radiant sun, lit up his people and provide them with a guidance on literature and arts

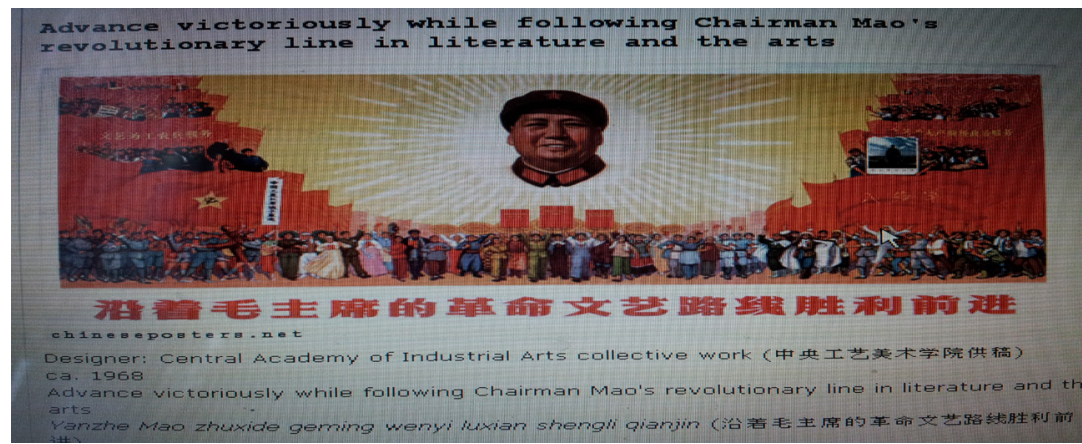

Source: International Institute of Social History, Digital Collections, www.iisg.nl/exhibitions/ chairman/chnintro.php. Retrieved on 14 April 2013.

Figure 9: Under the leadership of the Great Stalin, forward to Communism. The map shows the Communism under Stalin has widespread its influence across the globe

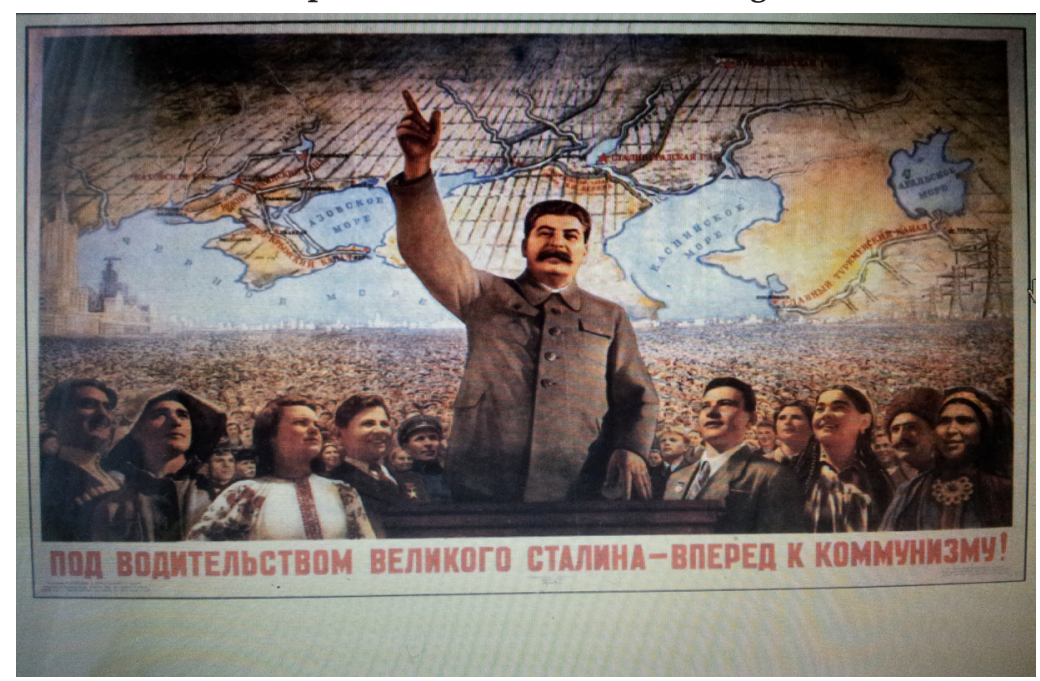

Source: Online Soviet Propaganda Posters Collections, www.sovietposters.com/showposter. php?poster=170. Retrieved on 11 April 2013. 
Figure 10: Mao's picture hanged on the wall, showing his omnipresence in the life of his people. Radio set, abundant of foods and healthy family depicts the wealthy life of workers' class family. Caption on the top: Chairman Mao gave us a happy life

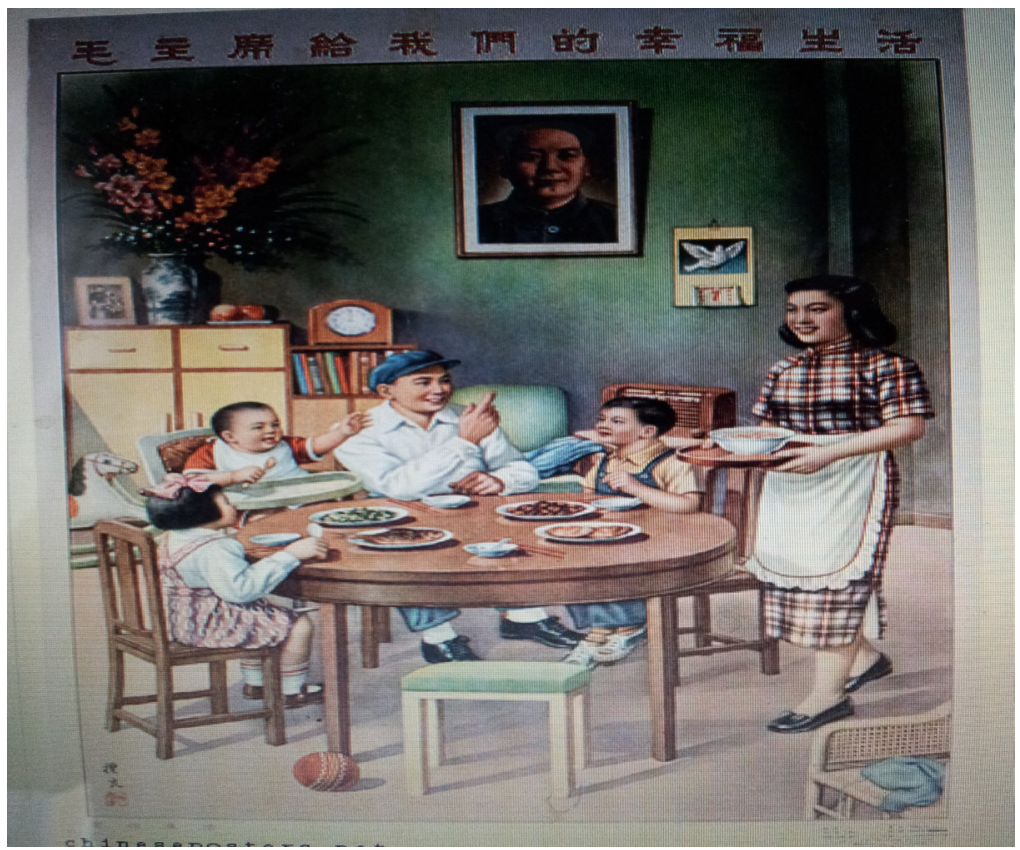

Source: International Institute of Social History, Digital Collections, www.iisg.nl/publications/ chineseposters.pdf . Retrieved on 11 April 2013.

The cult of personality also existed in the form of bestowal of titles, in speeches and poems. The leaders were vested by the people with great titles to remain perched on the top of the echelon. As the results, these positions helped them to control and command the people, because they were perceived as the savior of the people and had some kind of divine revelations or, in some cases, had supernatural powers. Mao Zedong was conferred with titles such as the Great Teacher, the Great Leader, the Great Helmsman, and the Supreme Commander. Mao was also depicted as a benevolent father, a man with love and passion for his people. His thoughts and writings were discerned as bright as the shining sun. On the other hand, his counterpart in the Soviet Union, Stalin, had indeed worshiped more than himself, for the fact that Stalin not only glorified by his people in Soviet, but also by the people of the Communist China. In fact, Mao himself was known as a 'Stalin Man'. In China, Stalin was eulogized as 'the stainless steel' and 'the perpetual sun' ${ }^{67}$

In celebrating Stalin's 70th birthday, a special magazine was released in Peking, China to venerate and glorify him. It was said, 
ostensibly, history has conferred upon Stalin the honor of 'Great man of the people', ${ }^{68}$ without clearly quoting the source of that so-called 'history'. In December 1949, a poem was published in a Chinese press laden with eulogies about Stalin's personality. Among the most enthralling stanzas in that long and trailing poem titled 'I Hail Thee, Stalin, Long May You Live', were:

Space cannot encompass your mightiness,
Nor time restrict your longevity,
You've lived seventy milliards of geological years,
You'll live seventy milliards more astronomical years,
You are endless, for ever living.

They say of old there was a savior Jesus,

He died once, and said to have been resurrected,

And you, Greater Liberator of the New Age,

Have died many times, and been resurrected as many times,

The death of Jesus was real, but his resurrection was false,

Your death, however, is false, but,

Your resurrection is for ever real.

The might of the atomic bomb is child play before you,

The threat of bacteriological war is a dream to you.

Your vigour will the waters of the poles into warm currents,

Your lustre will turn the Sahara desert into a fertile fields,

Your wisdom will change the courses of rivers and move sites of mountains,

The Earth will be made for ever youthful, and

Mankind for ever living in brotherly love. ${ }^{69}$

Furthermore, in commemorating Stalin's demise in 1953, a Chinese journalist in Peking wrote in 1954 that "One year has elapsed since Joseph Vissarionovich Stalin, the most beloved friend and enlightening teacher of the working class and laboring of the world, the great leader of international Communist movement, and the undaunted revolutionary warrior and gifted thinker passed away".${ }^{70}$ Undoubtedly, Stalin's image was seen as immortal and energetic in the heart of the communist followers.

\section{Conclusion}

The Cold War had witnessed one of the most intensive and relentless propaganda period in the modern history of mankind after the Hitler's reign in German. The world had to choose, whether to support the Capitalist or the Communist. Although some newly-independent 
countries tried to eschew from supporting any of them, obviously it was inevitable.

This article demonstrated that, with the promise of unabated affluence and modernity from the standpoints of the West, the Capitalist propaganda was generally perceived as more subtle, harmony and promising than that of the Communist, which was perceived as devoting much of its efforts in deifying their leaders and the Marxism-Leninism ideologies. However, the Communist, to some extent, had successfully influenced some countries by manipulating the sense of anti-colonialism, freedom and emancipation. The US bloc was depicted as the symbol of neo-colonialism. The battle for hearts and minds did not come to the end with the collapse of Soviet Union in the late $20^{\text {th }}$ century, indeed, sustained by the unilateral 'remnant' power of the Cold War, the United States.

\section{Notes}

1 Although there are various definitions for 'propaganda', they lead to the same conclusion that is an art of shaping and influencing the thought, emotions and behavior of individual or groups, with or without mutual consent. Among the scholars of propaganda studies were Carl von Clausewitz, Jacques Ellul, Edward L. Bernays, Leonard Doob, Richard Lambert, F.C. Bartlett, Noam Chomsky, Paul Linebarger, Garth S. Jowett and Victoria $\mathrm{O}^{\prime}$ Donnell.

2 Walter L. Hixson, Parting the Curtain: Propaganda, Culture, and the Cold War, 1945-1961, London: Macmillan Press Ltd., 1997, p. 4.

3 The Cold War was a hostile rivalry between the United States and the Soviet Union after the end of the Second World War until the collapse of the Soviet Union in 1991. It was a war of ideology and ideas between Capitalism and Communism and they never fought each other in a direct military confrontation, conversely involved in 'proxy wars' such as in Korea and Vietnam. Two blocs developed around the Soviet and the US, with other countries being forced to choose between the two blocs. Both sides offered an ideological, economic and social model extending as never before to the rest of world. Propaganda activities, information gathering and spying were part of winning the hearts and minds of allies and potential allies. For a brief understanding of the Cold War history, see Saki R. Dockill and Geraint Hughes (eds.), Palgrave Advances in Cold War History, New York: Palgrave Macmillan, 2006, pp. 1-25.

$4 \quad$ Marshall Plan was a US-sponsored program implemented following the Second World War to aid European countries that had been destroyed as a result of the war. Initiated by the Secretary of State, General George Marshall, the plan allotted over $\$ 13$ billion in aid to European nations and was the key in revitalizing the post-war economies of these nations. It was also a measure to protect Europe from the exploitation by an internal and external Communist threat. Simultaneously, it was also a stimulant 
to the US economy by establishing markets for American goods. This plan had institutionalized and legitimized the concept of US foreign aid programs, which have become an integral part of the US foreign policy. Cited in http:/ / history.state.gov/milestones/1945-1952/marshall-plan, retrieved on 20 February 2013. Also see in Charles P. Kindleberger, "The Marshall Plan and The Cold War", International Journal, Vol. 23, 1967-1968, pp. 376-377.

$5 \quad$ Frank A. Ninkovich, The Diplomacy of Ideas: US Foreign Policy and Cultural Relations, 1938-1950, Cambridge: Cambridge University Press, 1981, p. 160.

6 Memorandum from the Director of the Office of Information and Educational Exchange (Stone) to Acting Secretary of State Lovett, Washington, April 1, 1948, retrieved from www.state.gov/www/ about_state/intel/260_269.html on 27 October 2012.

7 White propaganda is carried out openly by revealing the source, which is usually comes from the government side and also the military at various levels. It is a flagrant effort in launching propaganda on the enemy or the target groups. See Garth S. Jowett and Victoria O' Donnell, Propaganda and Persuasion (5 $5^{\text {th }}$ Ed.), California: Sage Publications, Inc., 2012, p. 17.

8 Black propaganda aims to conceal the real source. It employs a trick by saying that it is delivered by another party, whereas the real sender does not reveal himself. It is often regarded as negative propaganda with extensive deception abilities. Ibid., p. 20.

$9 \quad$ Policy Planning Staff Memorandum, Washington, May 4, 1948, retrieved from www.state.gov/www/about_state/intel/260_269.html on 27 October 2012.

10 Noam Chomsky, Media Control: The Spectacular Achievements of Propaganda ( ${ }^{\text {nd }} E d$.), New York: Seven Stories Press, 2002, p. 31. Also see Nick Cullather, The CIA's Classified Account of Its Operations in Guatemala 19521954 ( $2^{\text {nd }} E$ d.), Stanford: Stanford University Press, 2006, pp. 8-10.

11 Top Secret, Memorandum for the Special Group (Augmented), from Brig. General Lansdale to General Taylor, "Institutional Planning: Operation Mongoose", 13 March 1962, retrieved from http://static.history.state. gov/frus/frus1961-63v10-12mSupp/pdf/d280.pdf on 2 January 2013.

12 Top Secret, Memorandum for Director of Central Intelligence, "Operation Mongoose- Future Course of Actions", 8 August 1962, retrieved from http://static.history.state.gov/frus/frus1961-63v10-12mSupp/pdf/d289. pdf on 2 January 2013.

13 Rhodri Jeffrey-Jones, The CIA and American Democracy, New Haven: Yale University Press, 1989, pp. 24-35.

14 Policy Planning Staff Memorandum, Washington, May 4, 1948, retrieved from www.state.gov/www/about_state/intel/260_269.html on 27 October 2012.

15 "Memorandum from the Assistant Director for Policy Coordination (Wisner) to Director of Central Intelligence Hillenkoetter", Washington, October 29, 1948, retrieved from www.state.gov/www/about_state/ intel/260_269.html on 22 October 2012. 
Ibid.

Ibid.

Substantive policy means in short, an expression of 'what the government is going to do?'. "Propaganda in the United Nations", Paper Prepared by the United Nations Planning Staff, Bureau of United Nations Affairs, Undated, retrieved from http:/ / history.state.gov/historicaldocuments/ frus195254v03/d27 on 22 October 2012.

Ibid.

Anti-British Propaganda by White Russians, FO 371/133459, File FC 1681/1, 12 January 1958.

Ibid.

Anti-US Propaganda Leaflet, FO 371/181027, File FC 1681/G, 26 July 1965. Ibid.

The US Fighting Man's Code, Office of Armed Forces Information and Education, Department of Defense, The United States of America,1959.

Ibid., p.2.

Ibid.

Ibid., p. 1.

Ibid., p. 2.

The Official CIA's Freedom of Information Act website, "The Kitchen Debate Transcript", 24 July 1959, www.foia.cia.gov/sites/default/files/ document.../16/1959-07-24.pdf. Retrieved on 20 January 2014.

The US Fighting Man's Code, p. 2.

Ibid.

Political Relations between China and Soviet Union, FO 371/120890, File FC 10338/1, 14 February 1956.

New China News Agency, 15 February 1956.

Paper Comparing Chinese Communism with Soviet Communism, FO 371/115219, File FC 10112/1, 30 June 1955.

Cited in Philip M. Taylor, British Propaganda in the $20^{\text {th }}$ Century, p. 227.

For further reading, see James B. Smith, “The British Information Research Department and Cold War Propaganda Publishing", in Greg Barnhisel \& Catherine Turner (eds.), Pressing the Fight - Print, Propaganda, and the Cold War, Amherst and Boston: University of Massachusetts Press, 2012, pp. 112-126 and Walter L. Hixson, Parting the Curtain, p. 121-123. Also see Tony Shaw, "The Information Research Department of the British Foreign Office and the Korean War, 1950-1953", Journal of Contemporary History, Vol. 34, No.2, April 2009.

Communist Propaganda, A Fact Book, 1957-1958, United States Information Agency, p.16.

Jane Dagras (ed.), The Communist International, 1919-1943, Documents, London: Frank Cass and Co. Ltd., 1971, pp. 166-168.

Ibid.

Franklin W. Houn, To Change A Nation, Propaganda and Indoctrination in Communist China, p.23.

Walter L. Hixson, Parting the Curtain p. 122. 
42 Amanda Laugesen, "Books for the World - American Book Programs in the Developing World, 1948-1968", Greg Barnishel and Catherine Turner (eds.), Pressing the Fight - Print, Propaganda and the Cold War, Boston: University of Massachusetts Press, 2010, p. 132.

43 Memorandum from the Executive Secretary of the National Security Council (Lay) to the Director of the Policy Planning Staff (Nitze), the Department of Defense Representative on the National Security Council Senior Staff (Nash), the Joint Chiefs of Staff Representative on the National Security Council Senior Staff (Wooldridge), and the Deputy Director of Central Intelligence (Jackson), May 14, 1951, www.history.state.gov./ historicaldocuments/frus1950-55Intel/d68. Retrieved on 26 January 2013. "Operation MONGOOSE Future Course of Action", Memorandum for Director of Central Intelligence, Top Secret, 8 August 1962. http:// www.globalsecurity.org/intell/library/reports/1997/frusX/index.html. Retrieved on 23 January 2013. Communist Propaganda, A Fact Book, 1957-1958, Washington: United States Information Agency, n.d., p. 40. Walter L. Hixson, Parting the Curtain, p. 133. "Peaceful coexistence" was firstly enunciated by Nikita Khrushchev at the Albanian Embassy in April 1957, with an intention to denounce Stalin's crimes. Khrushchev explained that, "We shall never take up arms to force the ideas of communism upon anybody. We do not need to do that, for the ideas of communism express the vital interests of the popular masses. Our ideas, the ideas of communism have such great vitality that no weapon can destroy them, that not even the nuclear weapon can hold up the development of these progressive ideas. Our ideas will capture the minds of mankind. The attempts of the imperialist to arrest the spread of the ideas of communism by force of arms are doomed to failure... for forty years now Messrs the capitalists have been reiterating that ... private ownership is omnipotent. We affirm that the ideas of communism are incomparably stronger, that these ideas will ultimately prevail. Therefore, we repeat again and again: let us compete, let us coexist peacefully". Cited in www.marxist.org/glossary/events/p/e.htm. Retrieved on 16 March 2013. For further reading, see George F. Kennan, "Peaceful Coexistence: A Western View" Foreign Affairs, Vol.38. No.2, January 1960, and Communist Propaganda, A Fact Book, 1957-1958, p. 6. Walter L. Hixson, Parting the Curtain, p. 134.

49 Karl Marx and Frederick Engels, The Communist Manifesto (Manifesto of the Communist Party), Mansfield Centre: Martino Publishing, 2012, p. 23. Ibid., p. 26.

51 George H. Bolsover, "Soviet Ideology and Propaganda", International Affairs (Royal Institute of International Affairs), Vol.24, No.2, April 1948, p. 173.

See Jung Woo Lee and Alan Bairner, "The Difficult Dialogue: Communism, Nationalism and Political Propaganda in North Korean Sport", Journal of Sport and Social Issues, 33(4), 2009, p. 392. 
$54 \quad$ Franklin W. Houn, To Change A Nation, Propaganda and Indoctrination in Communist China, pp. 41-42. For the brief history of the Party Schools system, see David Shambaugh, “Training China's Political Elite: The Party School System", The China Quarterly, December 2008. Christopher P. Loss, "Party School: Education, Political Ideology and the Cold War", The Journal of Policy History, Vol.16, No.1, 2004, pp.103-104. Also see George H. Bolsover, "Soviet Ideology and Propaganda", pp. 176-177.

56 George H. Bolsover, “Soviet Ideology and Propaganda”, p. 177.

57 Oliver Johnson, "Aesthetic Enemies: The "Two Cultures Theory at the Outset of the Cold War", David Welch and Jo Fox (eds.), Justifying WarPropaganda, Politics and the Modern Age, p. 271. Ibid., p. 272.

Cited in Patricia Powell and Joseph Wong, "Propaganda Posters from the Chinese Cultural Revolution" The Historian, Vol.59, Issue 4, June 1997, p. 784.

Chinese Propaganda Posters from the Collection of Michael Wolf, Koln: Taschen, 2008, p. 111.

Chinese Propaganda Posters from the Collection of Michael Wolf, p. 234. This poster depicts the Communist China's dream to become a modern state driven by the science and technology advancement.

Jonathan Charteris-Black, Politician and Rhetoric, The Persuasive Power of Metaphor (2 ${ }^{\text {nd }}$ Edition), Basingstoke: Palgrave Macmillan, 2011, p.52.

Timothy S. Benson, “The Cartoonists' Cold War", Frank Althaus \& Mark Sutcliffe (eds.), The Cold War in Cartoons, Drawing the Curtain, London: Fontanka Publications, 2012, p. 11.

Ibid., pp. 12-14.

Chinese Propaganda Posters from the Collection of Michael Wolf, p. 19.

"Rise of Stalin Cult", The Daily Mirror, London, 17 July 2008; "The Enduring Cult of Stalin, The Globe and Mail, Toronto, 25 March 2002; "Posters Recall Cult of Mao", The Press, Christchurch, 23 April 2007. China News, 5 March 1956.

Political Relations between China and Soviet Union, 1956, FO371/120890. Ibid. Ibid. 